\title{
Relaxation of distal colonic circular smooth muscle by nitric oxide derived from human leucocytes
}

\author{
S J Middleton, M Shorthouse, J O Hunter
}

\begin{abstract}
The role of nitric oxide (NO) as a mediator of colonic circular smooth muscle relaxation by human leucocytes was investigated. Granulocytes and mononuclear cells were obtained by gradient centrifugation of venous blood from healthy volunteers. Both cell types relaxed precontracted distal colonic circular smooth muscle in a concentration dependent manner. Muscle relaxation was inhibited by preincubation of cells with $\mathbf{N}^{\mathbf{G}}$-monomethyl-L-arginine (100 $\mu M / 1)$ but not by preincubation with $\mathbf{N}^{\mathrm{G}}$-monomethyl-D-arginine $\quad(100 \mu M / 1)$. Muscle relaxation by cells was reduced by $200 \mathrm{nM}$ oxyhaemoglobin and $10 \mu \mathrm{M}$ methylene blue but was increased by 60 units $/ \mathrm{ml}$ superoxide dismutase. Non-viable cells did not produce muscle relaxation. Activation of mononuclear cells by incubation with $100 \mathrm{nM} / 1$ FMet-Leu-Phe increased muscle relaxation, whereas activation of granulocytes did not. Granulocytes and mononuclear cells relax precontracted distal colonic circular smooth muscle in vitro by the release of NO that may contribute to motility disorders of the gut associated with inflammation.

(Gut 1993; 34: 814-817)
\end{abstract}

Colonic smooth muscle adjacent to the inflammed mucosa of patients with ulcerative colitis has diminished spontaneous activity. ${ }^{12}$ This leads to a reduction of muscle tone and loss of colonic segmentation, which are associated with diarrhoea. ${ }^{1-4}$

In 1980 Snape et $a l^{5}$ showed that the gastrocolonic reflex of patients with ulcerative colitis was attenuated. This was thought to result from electromechanical disassociation of colonic smooth muscle. ${ }^{6}$ Later, circular smooth muscle beneath the acutely inflammed mucosa of patients with ulcerative colitis was shown to have reduced contractility. ${ }^{5}$ The mediator of these mechanical abnormalities was not, however, identified.

We have previously reported relaxation of colonic circular smooth muscle by low concentrations of nitric oxide (NO). ${ }^{7}$ This is released by macrophages ${ }^{89}$ and neutrophils ${ }^{101}$ that infiltrate the colonic mucosa in large numbers during active ulcerative colitis ${ }^{12}$ and may affect the function of underlying smooth muscle.

Production of NO is from L-arginine via NO synthase. This reaction is stereospecifically inhibited by $\mathrm{N}^{\mathrm{G}}$-monomethyl-L-arginine but not $\mathrm{N}^{\mathrm{G}}$-monomethyl-D-arginine. ${ }^{13}$ Superoxide dismutase prolongs the half life of NO whereas oxyhaemoglobin traps free NO. ${ }^{14}$ 15 The activation of soluble guanylate cyclase by $\mathrm{NO}$ to produce the second messenger cyclic guanosine monophosphate (cGMP) is inhibited by methylene blue. ${ }^{16}$ In this study these agents were used to investigate whether granulocytes and mononuclear cells (collectively termed leucocytes in this paper) relax distal colonic circular smooth muscle by the release of NO.

\section{Materials and methods}

\section{MATERIALS}

Drugs and solutions were prepared on the day of use. The following were obtained from Sigma Chemicals Ltd and where necessary dissolved in distilled water immediately before use: acetylcholine, superoxide dismutase, $\mathrm{N}^{\mathrm{G}}$-methyl-Larginine, $\mathrm{N}^{\mathrm{G}}$-methyl-D-arginine, methylene blue, tetrodotoxin, FMet-Leu-Phe, and hypaque 1017 and 1119 . Indomethacin was initially dissolved in $10 \mathrm{mM} \mathrm{Na}_{2} \mathrm{CO}_{3}$ and further diluted in Krebs Henseleit solution. Oxyhaemoglobin was prepared from bovine haemoglobin (75\% methaemoglobin, Sigma Chemicals Ltd) and its purity was assessed spectrophotometrically according to the method described by Martin et al. ${ }^{15}$ Preparations were accepted if their concentrations of oxyhaemoglobin were greater than $90 \%$.

\section{PREPARATION OF TISSUE}

Male Wistar rats weighing $250-400 \mathrm{~g}$ were killed and strips of colonic circular smooth muscle were attached to isotonic transducers (Harvard, Kent, England) in $2 \mathrm{ml}$ organ baths and perfused by oxygenated $\left(95 \% \mathrm{O}_{2}, 5 \% \mathrm{CO}_{2}\right)$ Krebs Henseleit solution, composition: $(\mathrm{mM} / \mathrm{l}) \mathrm{NaCl} 118 ; \mathrm{KCl}$ 4.69; $\mathrm{MgSO}_{4} 1 \cdot 13 ; \mathrm{CaCl}_{2} 2 \cdot 56 ; \mathrm{NaHCO}_{3} 25$; $\mathrm{NaHPO}_{4} 1 \cdot 15$; glucose $5 \cdot 5$. This had a pH of $7 \cdot 4$ to $7 \cdot 6$ at $37^{\circ} \mathrm{C}$. Muscle strips were mounted with the longitudinal axis parallel to the direction of the circular muscle bundles. Temperature was regulated and $\mathrm{pH}$ monitored intermittently. Muscle strips were maintained under a tension of $3 \mathrm{~g}$, which produced near optimal contraction and experiments were commenced after a stabilisation period of two hours, which was found necessary in preliminary studies to ensure consistent muscle performance. Muscle strips were precontracted by $10 \mu \mathrm{M}$ acetylcholine and the mean amplitude of steady state contractions was measured for two minutes before and after the addition of leucocytes.

\section{CELL PREPARATION}

Venous blood from healthy human volunteers aged between 18 and 70 was collected with EDTA or glass shot beads (Scientific Furnishings, Macclesfield, England) to remove platelets 
Figure 1 Typical chart recording. Distal colonic circular smooth muscle contracted by acetylcholine $(10 \mu M)(A)$ and relaxed to granulocytes $\left(5 \times 10^{8}\right.$ cells $\left./ l\right)$ (G).

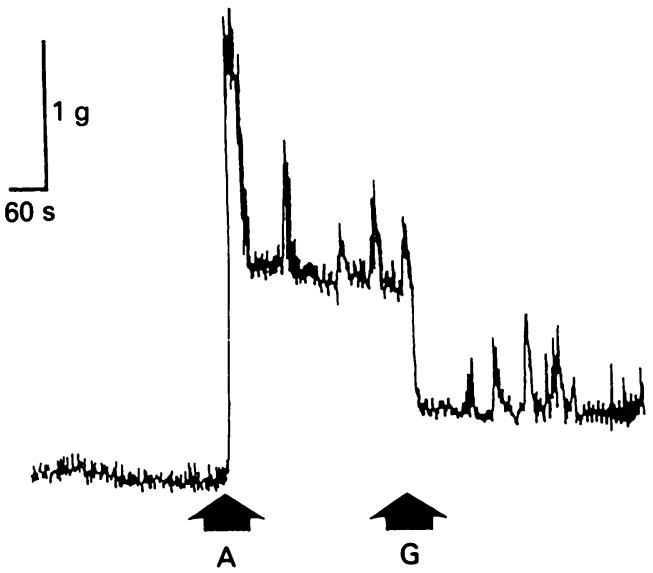

by defibrination. Blood $(5 \mathrm{ml})$ was layered above an $8 \mathrm{ml}$ bilayer of hypaque 1017 and 1119 in equal volumes and centrifuged at $700 \mathrm{~g}$ for 25 minutes. Mononuclear cells (macrophages and lymphocytes with or without platelets) and granulocytes (neutrophils, basophils, and eosinophils) were aspirated from two distinct layers. Leucocytes were washed twice in $10 \mathrm{ml}$ Krebs Henseleit solution $\left(37^{\circ} \mathrm{C}\right)$ containing $100 \mathrm{nM} / 1$ indomethacin (KHI) to inhibit prostaglandin synthesis, centrifuged at $200 \mathrm{~g}$ for 10 minutes, and resuspended in $5 \mathrm{ml} \mathrm{KHI}$. Leucocyte suspensions were accepted if red cell corpuscles were $<5 \%$ of total and viability was $>95 \%$ as judged by a tryphan blue exclusion test (Sigma Chemicals Ltd, England). This test was used to ensure a $100 \%$ death rate of cells frozen in liquid nitrogen. Cell suspensions were centrifuged at $200 \mathrm{~g}$ for 10 minutes and the pellet of cells added to the organ bath the bathing fluid of which was used to resuspend them for transfer. Experimental controls consisted of a similar procedure without the presence of cells.

TABLE I Substances with known effects on the NO-cGMP pathway affected relaxation of precontracted distal colonic circular smooth muscle by granulocytes

\begin{tabular}{|c|c|c|c|c|}
\hline & Cells $l^{-1}$ & $\begin{array}{l}\text { Mean muscle } \\
\text { relaxation } \\
(S E M)(\%)\end{array}$ & $\begin{array}{l}\text { No of } \\
\text { samples } \\
\text { (pairs) }\end{array}$ & $p$ Value \\
\hline $\begin{array}{l}\text { Viable } \\
\text { Non-viable }\end{array}$ & $\begin{array}{l}5 \times 10^{8} \\
5 \times 10^{8}\end{array}$ & $\begin{array}{l}78(11 \cdot 7) \\
0 \cdot 37(3 \cdot 3)\end{array}$ & 8 & $<0.005$ \\
\hline Control & $1 \times 10^{8}$ & $50(9 \cdot 5)$ & & $<0.005$ \\
\hline Oxyhaemoglobin & $1 \times 10^{8}$ & $25(5 \cdot 9)$ & 8 & \\
\hline $\begin{array}{l}\mathrm{N}^{\mathrm{G}} \text {-monomethyl-D-arginine } \\
\mathrm{N}^{\mathrm{G}} \text {-monomethyl-L-arginine }\end{array}$ & $\begin{array}{l}1 \times 10^{8} \\
1 \times 10^{8}\end{array}$ & $\begin{array}{l}53(11 \cdot 8) \\
1.8(3.9)\end{array}$ & 9 & $<0.02$ \\
\hline Control & $\begin{array}{l}5 \times 10^{8} \\
5 \times 10^{8}\end{array}$ & $\begin{array}{l}73(13 \cdot 5) \\
24(6 \cdot 1)\end{array}$ & 7 & $<0.01$ \\
\hline $\begin{array}{l}\text { Methylene blue } \\
\text { Control }\end{array}$ & $7.5 \times 10^{7}$ & $37(11 \cdot 6)$ & & \\
\hline Superoxide dismutase & $7 \cdot 5 \times 10^{7}$ & $96(3.6)$ & 7 & $<0.003$ \\
\hline
\end{tabular}

Mean relaxations are compared with controls by Student's $t$ test for paired data.

TABLE II Substances with known effects on the NO-cGMP pathway affected relaxation of precontracted distal colonic circular smooth muscle by mononuclear cells

\begin{tabular}{|c|c|c|c|c|}
\hline & Cells $l^{-1}$ & $\begin{array}{l}\text { Mean muscle } \\
\text { relaxation } \\
(S E M)(\%)\end{array}$ & $\begin{array}{l}\text { No of } \\
\text { samples } \\
\text { (pairs) }\end{array}$ & p Value \\
\hline $\begin{array}{l}\text { Viable } \\
\text { Non-viable }\end{array}$ & $\begin{array}{l}5 \times 10^{8} \\
5 \times 10^{8}\end{array}$ & $\begin{array}{l}46(13 \cdot 8) \\
(23 \% \text { contraction })(12)\end{array}$ & 7 & $<0.005$ \\
\hline Control & $8 \times 10^{x}$ & $63(8 \cdot 3)$ & 9 & $<0.005$ \\
\hline Oxyhaemoglobin & $8 \times 10^{8}$ & $25(7)$ & & \\
\hline $\begin{array}{l}\mathrm{N}^{\mathrm{G}} \text {-monomethyl-D-arginine } \\
\mathrm{N}^{\mathrm{G}} \text {-monomethyl-L-arginine }\end{array}$ & $\begin{array}{l}2 \times 10^{8} \\
2 \times 10^{8}\end{array}$ & $\begin{array}{c}33(12 \cdot 1) \\
7 \cdot 7(8 \cdot 7)\end{array}$ & 12 & $<0.05$ \\
\hline $\begin{array}{l}\text { Control } \\
\text { Methylene blue }\end{array}$ & $\begin{array}{l}5 \times 10^{8} \\
5 \times 10^{8}\end{array}$ & $\begin{array}{l}43(20) \\
(3 \cdot 5 \% \text { contraction })(15)\end{array}$ & 7 & $<0.01$ \\
\hline Control & $5 \times 10^{7}$ & $12(7 \cdot 6)$ & 15 & $<0.02$ \\
\hline Superoxide dismutase & $5 \times 10^{7}$ & $54(11 \cdot 7)$ & & \\
\hline
\end{tabular}

Mean relaxations are compared with controls by Student's $t$ test for paired data.

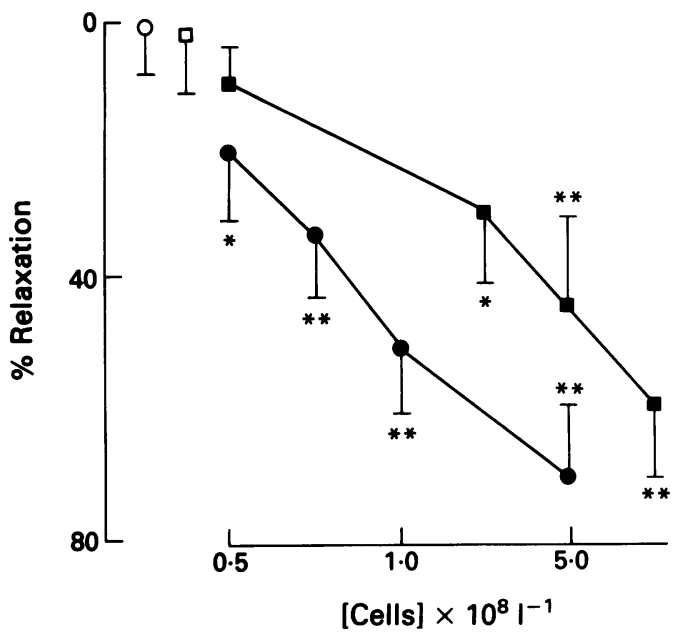

Figure 2 Granulocytes (O) and mononuclear cells $(\square)$ relaxed precontracted distal colonic circular smooth muscle in a concentration dependent manner. Mean percentage relaxations of muscle (SEM) are shown. Collective means and standard errors of controls for both groups of cells are indicated by open symbols. Data were analysed with Student's $t$ test for paired data. ${ }^{\star} p<0.05 ;{ }^{\star \star} p=0.01$.

\section{STATISTICS}

Data obtained from each experiment approximated to a normal distribution and were analysed with Student's $t$ test for paired data. Data are shown as means (SEM).

\section{Results}

\section{EFFECT OF LEUCOCYTES ON PRECONTRACTED}

MUSCLE

Granulocytes and mononuclear cells produced concentration dependent relaxations of circular smooth muscle precontracted with $10 \mu \mathrm{M} / 1$ acetylcholine (Figs 1 and 2). Non-viable leucocytes did not relax muscle. Removal of platelets did not alter relaxation of precontracted muscle by $1 \times 10^{8} / 1$ mononuclear cells which was $22(7) \%$ with platelets and $26(10 \%)$ without $(\mathrm{p}>0 \cdot 1$, $\mathrm{n}=7$ pairs). Therefore platelets were not removed from mononuclear cell suspensions in the subsequent experiments as this process reduced cell yield. Substances known to affect the NO-cGMP pathway affected muscle relaxation by leucocytes (Tables I and II). Addition of $200 \mathrm{nM}$ oxyhaemoglobin and $10 \mu \mathrm{M}$ methylene blue to the organ bath, one and 10 minutes before cells respectively, reduced muscle relaxation. Incubation of cells for 45 minutes with $100 \mu \mathrm{M} \mathrm{N} \mathrm{N}^{\mathrm{G}}$-monomethyl-L-arginine reduced muscle relaxation, but $100 \mu \mathrm{M} \mathrm{N} \mathrm{N}^{\mathrm{G}}$-monomethyl$D$-arginine had no effect. Superoxide dismutase $(60$ units $/ \mathrm{ml}$ ) added one minute before leucocytes produced an increase in muscle relaxation. Tetrodotoxin (100 $\mathrm{nM})$ did not affect muscle relaxation by leucocytes $(n=5$, not shown). Leucocytes were activated by incubation for one hour with FMet-Leu-Phe $100 \mathrm{nM}$. Activated mononuclear cells $\left(5 \times 10^{7} / 1\right)$ caused a mean muscle relaxation of $43.6(15) \%$ compared with $8 \cdot 3(4) \%$ by paired non-activated cells $(\mathrm{n}=10$ pairs, $\mathrm{p}<0.05)$. Activation of granulocytes did not increase muscle relaxation (mean relaxation by activated granulocytes $21 \cdot 3(10) \%$ compared with $18 \cdot 4(6) \%$ by non-activated cells $(\mathrm{n}=12$ pairs, $\mathrm{p}=0 \cdot 7)$ ). 


\section{Discussion}

We have shown that granulocytes and mononuclear cells relax colonic circular smooth muscle strips contracted by acetylcholine. The mediator of muscle relaxation is unlikely to be a prostanoid as leucocytes were incubated with $100 \mathrm{nM}$ indomethacin. Leucotrienes produce contraction of this tissue and thromboxane has no effect. ${ }^{17}$ Muscle relaxation was increased by superoxide dismutase and reduced by oxyhaemoglobin and preincubation with methylene blue. Incubation of effector phagocytes with $\mathrm{N}^{\mathrm{G}}$-monomethyl-L-arginine reduced muscle relaxation, whereas incubation with $\mathrm{N}^{\mathrm{G}}$ monomethyl-D-arginine had no effect. Only viable mononuclear cells and granulocytes caused muscle relaxation, suggesting that the relaxing factor is not stored by these cells. Muscle relaxation was not affected by tetrodotoxin and therefore unlikely to be mediated by neural elements. These findings strongly support the suggestion that effector phagocytes relax circular smooth muscle by the release of NO.

Our results are in agreement with those of others who found that activated and nonactivated macrophages ${ }^{8918}$ and granulocytes ${ }^{1011}$ relax vascular smooth muscle by release of NO that is synthesised from L-arginine by a stereospecific enzyme, NO synthase. Release of NO is increased by activation of macrophages, ${ }^{19}$ but not granulocytes, ${ }^{20}$ possibly because of the simultaneous increase in production of superoxide anions that react with NO. ${ }^{1121}$

Leucocytes forming part of the inflammatory infiltrate of ulcerative colitis and at other sites of inflammation in the gastrointestinal tract may produce smooth muscle relaxation via release of NO. Diffusion of NO through the submucosa might be facilitated by the formation of a stabilising adduct with a carrier molecule such as cysteine, or a thiol containing protein such as albumin. ${ }^{21-23}$ Formation of these S-nitrosothiol compounds has been shown to increase the biological half life of NO in physiological solutions from three to five seconds ${ }^{24} 25$ to about 40 minutes. ${ }^{26}$ Pacemaker cells are located on the submucosal surface of the circular muscle. ${ }^{27}$ These cells not only produce electrical slow wave pacemaker activity responsible for the spontaneous mechanical activity of circular smooth muscle but also form a regenerative surface that propagates this activity. Damage to these cells reduces electrical pacemaker activity and impedes its propagation ${ }^{28} \mathrm{NO}$ or its adduct may inhibit this pacemaker activity or the response of myocytes to it, thus reducing spontaneous mechanical activity and causing a reduction in smooth muscle tone. In severe inflammation where the muscularis propria is infiltrated by leucocytes, profound dilatation may occur such as that seen in toxic megacolon. ${ }^{29}$ It has recently been shown that NO relaxes the human internal anal sphincter. ${ }^{30}$ This may contribute to the urgency to stool often associated with ulcerative colitis if inflammatory cells release NO in sufficient amounts to affect sphinteric function.

Smooth muscle relaxation by NO is mediated by raising intracellular cGMP concentration, which inhibits the release of calcium from intracellular stores ${ }^{163132}$ and may produce mechanical changes without alterations in membrane potential..$^{33}$ This may explain the electromechanical disassociation found by Snape $e t a l$ as the cause of reduced gastrocolonic reflex in patients with ulcerative colitis. ${ }^{5}$

In conclusion, we have shown that human granulocytes and mononuclear cells generate NO in quantities sufficient to relax distal colonic smooth muscle. This may contribute to disorders of motility associated with inflammation.

We are indebted to Professor A W Cuthbert for advice, encouragement, and use of facilities, and to his staff at the Department of Pharmacology, Cambridge University, particularly $\mathrm{Mr} \mathrm{T}$ Redmond and Mr B Gilson for their invaluable technical assistance. We also thank Miss A Lee for preparation of the manuscript.

1 Kern F Jr, Almy TP, Abbot FK, Bogdonoff MD. The motility of the colon in non specific ulcerative colitis. Gastroenterology 1951; 19: 492-503.

2 Garrett JM, Sauer WG, Moertel CG. Colonic motility in ulcerative colitis after opiate administration. Gastroenterology 1967; 53: 93-100.

3 Connell AM. The motility of the pelvic colon. Gut 1962; 3: 342-8.

4 Spriggs EA, Code CF, Bargen JA, Curtiss RK, Hightower NC $\mathrm{Jr}$. Motility of the pelvic colon and rectum of normal persons and patients with ulcerative colitis. Gastroenterology
$1951 ; 19: 480-91$.

5 Snape WJ, Matarazzo SA, Cohen S. Abnormal gastrocolonic response in patients with ulcerative colitis. Gut 1980; 21: 392-6.

6 Snape WJ, Kao HW. Role of inflammatory mediators in colonic smooth muscle function in ulcerative colitis. Digestive Diseases and Sciences 1988; 33: 65S-70S

7 Middleton SJ, Shorthouse M, Hunter JO. Nitric oxide (NO) relaxes mammalian distal colonic circular smooth muscle. Clin Sci 1991; 81 (suppl 25): 10.

8 Salvemini D, De Nucci G, Grylewski RJ, Vane JR. Human neutrophils and mononuclear cells inhibit platelet aggreganeutrophils and mononuclear cells inhibit platelet aggrega1989; 86: 6328-32.

9 Stuehr DJ, Gross SS, Sakuma I, Levi R, Nathan CF. Activated murine macrophages secrete a metabolite of arginine with the bioactivity of endothelium-derived relaxing factor and the chemical reactivity of nitric oxide. $\mathcal{f} E x p$ Med 1989; 169: 1011-20.

10 McCall TB, Boughton-Smith NK, Palmer RMJ, Whittle BJR, Moncada S. Synthesis of nitric oxide from L-arginine by neutrophils. Biochem f 1989; 261: 293-6.

11 Schmidt HHHW, Seifert R, Bohme E. Formation and release of nitric oxide from human neutrophils and HL-60 cells induced by a chemotactic peptide, platelet activating factor ind leukotriene B4. Federation of European Biochemical Societies 1989; 244: 357-60.

12 Truelove SC, Witts LJ. Cortisone in ulcerative colitis. 1. BMF 1955; 29: 1041-8.

13 Rees DD, Palmer RMJ, Hodson HF, Moncada S. A specific inhibitor of nitric oxide formation from $\mathrm{L}$-arginine attenuates endothelium-dependent relaxation. $\mathrm{Br} \mathcal{F}$ Pharmaco 1989; 96: 418-24.

14 Gryglewski RJ, Palmer RMJ, Moncada S. Superoxide anion is involved in the breakdown of endothelium-derived vascular relaxing factor. Nature $1986 ; 320$ : 454-6.

15 Martin W, Smith JA, White DG. The mechanisms by which haemoglobin inhibits the relaxation of rabbit aorta induced by nitrovasodilators, nitric oxide, or bovine retractor penis inhibitor factor. $B r \mathcal{F}$ Pharmacol 1986; 89: 563-71.

16 Nakatsu K, Diamond J. Role of cGMP in relaxation of vascular and other smooth muscle. Can $\mathcal{f}$ Physiol Pharmacol $1989 ; 67: 251-62$

17 Middleton SJ, Hunter JO. Identification of spontaneous high and low frequency contractions in colonic smooth muscle under neural regulation mediated by nitric oxide. Clin $\mathrm{Sci}$ 1992; 82 (suppl 26): 18.

18 Marletta MA, Yoon PS, Iyengar R, Leaf CD, Wishnok JS. Macrophage oxidation of $\mathrm{L}$-arginine to nitrite and nitrate: nitric oxide is an intermediate. Biochemistry 1988; 27 8706-11.

19 Iyengar R, Stuehr DJ, Marletta MA. Macrophage synthesis of nitrite, nitrate and N-nitrosamines: Precursors and role of
the respiratory tract. Proc Natl Acad Sci 1987; 84: 6369-73.

20 Wright CD, Mulsch A, Busse R, Osswald H. Generation of nitric oxide by human neutrophils. Biochem Biophys Res nitric oxide by human neut

21 McCall T, Vallance P. Nitric oxide takes centre-stage with newly defined roles. Trends in Pharmacologv 1992; 13: 1-6.

22 Thornbury KD, Ward SM, Dalziel HH, Carl A, Westfall DP Sanders KM. Nitric oxide and nitrosocysteine mimic nonSanders KM. Nitric oxide and nitrosocysteine mimic nonadrenergic, noncholinergic hyperpolarization

23 Ignarro LJ. Nitric oxide. A novel signal transduction mechanism for transcellular communication. Hypertension 1990 16: 477-83.

24 Palmer RMJ, Ferrige AG, Moncada S. Nitric oxide release accounts for the biological activity of endothelium-derived relaxing factor. Nature $1987 ; 327: 52+6$. 
25 Harbison RG, Wood KS, Kadiwitz PJ. Activation of purified soluble guanylate cyclase by endothelium-derived relaxin factor from intrapulmonary artery and vein: stimulation by acetylcholine, bradykinin and arachidonic acid. $\mathcal{F}$ Pharmaco Exp Ther 1986; 237: 893-900.

26 Stamler JS, Simon DI, Osborne JA, Mullins ME, Jaraki O, Michel T, et al. S-Nitrosylation of proteins with nitric oxide: Michel T, et al. S-Nitrosylation of proteins with nitric oxide:
Synthesis and characterisation of biologically active com Synthesis and characterisation of biologically activ
pounds. Proc Natl Acad Sci USA 1992; 89: 444-8.

27 Smith TK, Reed JB, Sanders KM. Interaction of two electrical pacemakers in muscularis of canine proximal colon. Am Physiol 1987; 252: C290-9.

28 Sanders KM, Stevens R, Burke E, Ward SM. Slow waves actively propagate at submucosal surface of circular layer in canine colon. Am f Physiol 1990; 259: G258-63.

29 Heppell J, Farkouh E, Dube S, Peloquin A, Morgan S,
Bernard D. Toxic megacolon: An analysis of 70 cases. Dis Colon Rectum 1986; 29: 789-92.

30 Burleigh DE. $\mathrm{N}^{\mathrm{G}}$-nitro-L-arginine reduces nonadrenergic, noncholinergic relaxations of human gut. Gastroenterology 1992; 102: 679-83.

31 Arnold WP, Mittal CK, Katsuki S, Murad F. Nitric oxide activates guanylate cyclase and increases guanosine $3^{\prime}, 5^{\prime}$ cyclic monophosphate levels in various tissue preparations.

32 Middleton SJ, Shorthouse M, Hunter JO. cGMP mediates relaxation of distal colonic circular smooth muscle by nitric oxide. Gut 1992; 33 (Suppl 2): S12.

33 Ito $\mathbf{Y}$, Kitamura K, Kuriyama $\mathbf{H}$. Actions of nitroglycerine on the membrane and mechanical properties of smooth muscle of the coronary artery of the pig. Br $\mathcal{F}$ Pharmacol 1980; 70: 197-204. 